MRS Selects John Ballance

To Direct a New, Centralized Headquarters

A Select Committee chaired by President-elect C.W. "Woody" White has recommended, and the Society endorsed, the appointment of John B. Ballance as MRS Executive Director. Ballance already has established a new headquarters for the Society in Pittsburgh, and begun to play a role in the development of the Society which promises to advance its growth by enhancing the professional development it offers to materials scientists, engineers and technicians.

Ballance, 42, most recently was Editor of The Journal of Metals. Trained in materials technology and experienced in administration, he assumes overall responsibility for the management of MRS operations in support of our programs and services for members.

President Harry J. Leamy established the Select Committee to explore the feasibility of establishing a headquarters function and staff. (As described elsewhere in these pages, Executive Secretary Ernest M. Hawk has been anxious to devote more of his time to non-MRS matters.) "The Society's rapid growth," Leamy says, "has taxed the ability of our volunteer and part-time infrastructure to meet our needs - and to anticipate the needs we will experience as we continue to enhance the services we can be expected to provide. The Select Committee came back with an outstanding proposal to structure a headquarters equipped to facilitate the Society's development, and an outstanding administrator in the person of John Ballance to organize and direct it."

Select Committee Chairman White says the establishment of a new headquarters will "make it possible to bring under one roof the innumerable staff functions required to organize and conduct our meetings, and to carry out

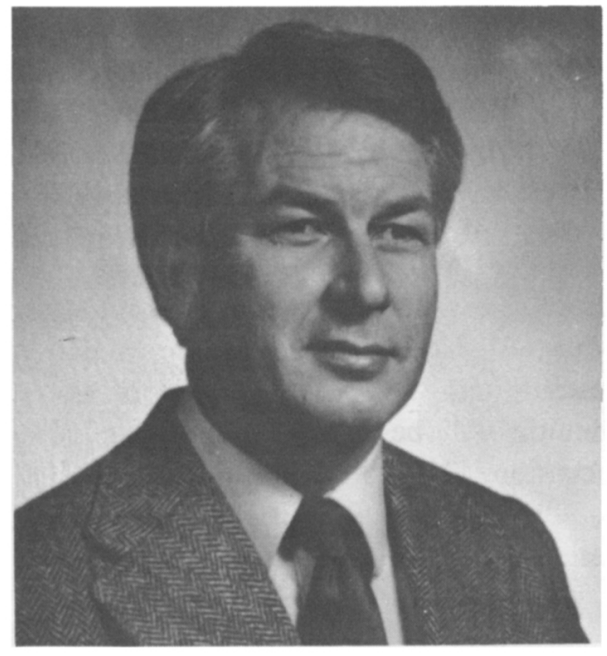

JOHN B. BALLANCE

the other programs the Society has in place. As we have grown these logistical problems have strained our human resources virtually to the limit. For increased efficiency and to permit future growth, we found the establishment of the new headquarters to be imperative."

White said that in addition to the alternative of creating a permanent staffed headquarters, his committee solicited and received proposals from independent management-consulting firms and other scientific organizations that supply administrative services. "What emerged," he says, "is a consensus, which the Council strongly endorsed, that the headquarters would provide the most responsive and costeffective mechanism by which the Society could administer and expand its offerings.

"We were fortunate to find an individual of John's caliber to accept this responsibility," White adds.

The other members of the Select Committee were Vice President Elton N. Kaufmann, Secretary Richard L. Schwoebel, Treasurer Kathleen C. Taylor, Councillor Kenneth A. Jackson and Leamy.

\section{John Ballance}

"The Materials Research Society has very great strength in its people," Executive Director John B. Ballance says. "I see my job as providing them the resources and support they will utilize to advance the Society."

John B. Ballance was born May 28,1941 , the eldest of four boys of Battle Ransome Ballance and Julia Hargis Ballance, who also have four daughters. A native of Four Oaks, NC, Ballance took bachelors and masters degrees in metallurgical engineering from North Carolina State University.

In his first job, in the Research Center of Republic Steel Corp., Ballance worked with lightweight steels used in automobiles and other applications. He holds two patents, one on bainitic and the other on highly formable high-strength, low-alloy steels.

In 1974 he joined Brush Wellman, also in Cleveland, where he specialized in limiteduse, specialty-application metals, notably beryllium copper. In 1978 he was named Editor of The Journal of Metals, published by TMS-AIME, and Director of Publications of The Metallurgical Society. His responsibilities extended beyond the editorial content of the Society's publications to their circulation, advertising and promotion.

Ballance is married and has a daughter, Heather, born in 1982. His wife, Carol, teaches hearing-impaired and handicapped children. They reside in Pittsburgh. 